Policy Research Working Paper 2483

The Credit Crunch in East Asia

What Can Bank Excess Liquid Assets Tell Us?

Pierre-Richard Agénor

Joshua Aizenman

Alexander Hoffmaister
A two-step approach is used to assess the extent to which the credit crunch in East Asia was supply- or demanddriven. The results for Thailand suggest that the contraction in bank lending that accompanied the crisis was the result of supply factors

The World Bank

World Bank Institute

Economic Policy and Poverty Reduction Division

November 2000 
Policy Research Working Paper 2483

\section{Summary findings}

Agénor, Aizenman, and Hoffmaister propose a two-step approach for assessing the extent to which the fall in credit in crisis-stricken East Asian countries was a supplyor demand-induced phenomenon.

The first step involves estimating a demand function for excess liquid assets held by commercial banks.

The second step involves establishing dynamic projections for the periods after the crisis and assessing whether or not residuals are large enough to be viewed as indicators of an "involuntary" accumulation of excess reserves.

The results for Thailand suggest that the contraction in bank lending that accompanied the crisis was the result of supply factors. Thai firms (presumably small and medium-size ones) faced binding constraints in getting access to credit markets after the crisis.

This paper-a product of the Economic Policy and Poverty Reduction Division, World Bank Institute-is part of a larger effort in the institute to understand the macroeconomic effects of credit market imperfections. Copies of the paper are available free from the World Bank, $1818 \mathrm{H}$ Street NW, Washington, DC 20433. Please contact Maria Gosiengfiao, room J4-282, telephone 202-473-3363, fax 202-676-9810, email address mgosiengfiao@worldbank.org. Policy Research Working Papers are also posted on the Web at www.worldbank.org/research/workingpapers. Pierre-Richard Agénor may be contacted at pagenor@worldbank.org. November 2000. (32 pages)

The Policy Research Working Paper Series disseminates the findings of work in progress to encourage the exchange of ideas about development issues. An objective of the series is to get the findings out quickly, even if the presentations are less than fully polished. The papers carry the names of the authors and should be cited accordingly. The findings, interpretations, and conclusions expressed in this paper are entirely those of the authors. They do not necessarily represent the view of the World Bank, its Executive Directors, or the countries they represent. 


\title{
The Credit Crunch in East Asia: What can Bank Excess Liquid Assets Tell us?
}

\author{
Pierre-Richard Agénor, ${ }^{*}$ Joshua Aizenman, ${ }^{* *}$ \\ and A. Hoffmaister***
}

JEL Classification Numbers: E42, F31, F41

${ }^{*}$ The World Bank, Washington DC 20433; **Department of Economics, Dartmouth College, Hanover NH 03755, and NBER; ${ }^{* * *}$ International Monetary Fund, Washington DC 20431, and Central Bank of Costa Rica. We would like to thank, without implication, Stijn Claessens, Homi Kharas, and Luis Pereira da Silva for helpful discussions and comments, Stephen Schwartz for helping us obtain some of the data used here, and Nihal Bayraktar for excellent research assistance. 



\section{Introduction}

The causes of the sharp decline in credit to the private sector in the crisisstricken countries of East Asia (as documented, for instance, by Alba et al. (1999)) continues to generate much controversy among economists. Some observers have argued that the fall in bank credit resulted from a credit crunch, that is, increased incidence of credit rationing. Others have suggested that the decline in bank loans may have resulted instead from the reduction in the demand for credit, itself a consequence of the contraction in aggregate demand and the fall in output that accompanied the crisis.

Whether a contraction in domestic credit is due to supply or demand factors has, of course, important implications for monetary and fiscal policies. If banks are unwilling to lend because, for instance, of a perceived increase in the risk of default that cannot be internalized by raising the cost of borrowing, attempts to increase liquidity and force interest rates down to stimulate aggregate demand and the demand for loans will prove largely ineffective. By contrast, if banks are unable to lend (because firms are curtailing their demand for credit as a result, for instance, of a perceived weakening in future demand and thus lower profits), easing the fiscal stance may help expand aggregate demand and generate an expansion in credit.

Recent attempts at determining whether the fall in bank credit in Asia's crisis-stricken countries resulted from supply or demand factors have provided mixed results. Several papers have used survey evidence on changes in bank lending and firm borrowing during the crisis to assess the incidence of a credit crunch. Some of the better-known studies include those of Domaç and Ferri (1999a), Dollar and Hallward-Driemeier (1998), Dwor-Frecaut, HallwardDriemeier, and Colaco (1999), and Ito and Pereira da Silva (1999). The latter study, in particular, used survey data for commercial banks to argue in favor of a credit crunch in Thailand during the period extending from mid-1997 
(immediately after the inception of the crisis) to early $1998 .{ }^{1}$ By contrast, Dollar and Hallward-Driemeier (1998) found little evidence of a credit crunch in Thailand-in the sense of firms with orders but unable to get credit to finance working capital needs. The evidence that they gathered suggests, on the contrary, that constraining factors on output expansion appeared to have been weak perceived demand and the sharp increase in the price of imported inputs resulting from the large nominal exchange rate depreciation that occurred in the months following the crisis. ${ }^{2}$ Along the same lines, DworFrecaut, Hallward-Driemeier, and Colaco (1999) analyzed the results of a survey conducted between November 1998 and February 1999 in Indonesia, Korea, Malaysia, the Philippines, and Thailand of 3,700 firms, covering major manufacturing and export sectors. They found that at prevailing interest rates, credit availability in the aggregate was not seen by the surveyed firms as a major constraint on production plans. They concluded therefore that the fall in credit was demand-driven.

Because survey evidence can be seriously biased-for instance, tight credit can reduce demand, and lack of demand may be perceived as the main problem by respondents - several other studies have relied on other methodologies. Domaç and Ferri (1999b), for instance, used a conceptual framework based on the "credit view" of monetary policy to analyze the existence of a credit crunch in Indonesia, Korea, Malaysia, the Philippines, and Thailand. ${ }^{3}$

\footnotetext{
${ }^{1}$ As noted by Ito and Pereira da Silva (1999), if the nominal credit stock is deflated by a composite index consisting of consumer prices and the nominal exchange rate (in order to account for the fact that a significant share of the loans provided by Thai commercial banks and finance companies just before the crisis were denominated in foreign currency and the book value of these loans was recorded at the current exchange rate), the deceleration in the rate of growth of real credit to the private sector was quite dramatic in that country: a year-on-year contraction of $\mathbf{- 2 . 4}$ percent in August 1997, -5.3 percent in October, -12.2 percent in November and -18 percent in December (Ito and Pereira da Silva (1999, p. 14)).

${ }^{2}$ It should also be noted that in Thailand, firms had contracted large amounts of unhedged short-term debt on world capital markets and were thus highly vulnerable to currency depreciation; see Alba et al. (1999).

${ }^{3}$ See Walsh (1998, Chapter 7) for a detailed discussion of the credit channel of monetary policy, particularly the role of informational asymmetries.
} 
Specifically, they argued that a widening of the spread between the lending rate and a representative rate on risk-free assets while at the same time real bank credit is falling represents prima facie evidence that the demand for loans could not have declined by more than the supply of credit. They found evidence (based on the spread between bank lending rates and corporate bonds) consistent with this view and thus concluded that the credit crunch was widespread, affecting particularly small-sized firms, for whom close substitutes for bank credit are unavailable. ${ }^{4}$

By contrast, Ghosh and Ghosh (1999) used a switching regression framework for analyzing the behavior of real private credit in Korea and Indonesia. They estimated both supply and demand functions for credit and determined, for each period, whether supply or demand was the constraining factor. They found that, in Indonesia (where the crisis started in September 1997), there was evidence of a credit crunch in the third and fourth quarters of 1997. By the end of the first of 1998, however, the decline in actual credit reflected mostly the fall in the demand for loans induced by the deepening recession. Similarly, in Korea (where the crisis started a month later) they found evidence of a credit crunch in the last quarter of 1997, but from the first quarter of 1998 onward, the constraining factor appears to have been the demand for credit. Thus, and in contrast to the survey-based evidence, the study by Ghosh and Ghosh provides evidence of both demand and supply factors at play: the fall in private sector lending in East Asia (at least in Korean and Indonesia) may have been the result of bank tightening of credit supply in the first stage, and a drop in borrower demand in the second stage.

This paper attempts to shed additional light on the current controversy by proposing a two-step econometric approach. The first step is based on

\footnotetext{
${ }^{4}$ It should be noted, however, that spreads can increase for a variety of reasons. For instance, in the model of Agenor and Aizenman (1998), an increase in spreads may result from an expected rise in monitoring costs associated with lending operations. An expected tightening in prudential regulations requiring banks to hold more liquid assets may also lead to higher spreads, to the extent that these assets yield lower returns (and thus lower income) than other assets that the banks would have chosen otherwise.
} 
the estimation of a demand function for excess reserves (or liquid assets) by commercial banks that captures, in particular, the precautionary motive for holding nonremunerated assets. The second step consists in establishing dynamic projections for the periods following the crisis and assessing whether actual values of excess reserves are "close enough" (in a statistical sense that is made more precise below) to those predicted by a stable regression model. If that is the case, the increase in actual holdings of excess reserves can be construed as consistent with a supply-induced reduction in credit; if that is not the case, the accumulation of excess liquid assets can be seen as "involuntary" - in which case the slowdown in credit is more likely to reflect a reduction in demand. Underlying our approach is the view that increased incidence of rationing-particularly of the more risky categories of borrowers-may take the form of increases in excess reserve holdings motivated, in the context of a crisis, by higher perceived uncertainty or risk of default. Greater volatility of deposits (relative to currency holdings) and increased riskiness of lending, in particular, may also prompt banks to hold higher levels of precautionary excess reserves.

The remainder of the paper is structured as follows. Section II presents a theoretical model of the demand for excess liquid reserves by commercial banks in the presence of both liquidity risk and real sector volatility. The impact of various variables (including required reserves and funding costs) on the demand for excess reserves is also analyzed. Section III presents estimates of the resulting demand equation for Thailand; it also discusses the in-sample properties of the model. Section IV examines the performance of the dynamic forecasts generated by the model and analyzes whether the regression forecasts are consistent with the hypothesis of a credit crunch. The last section summarizes the results and offers some concluding remarks. 


\section{A Model of Excess Liquid Assets}

At the heart of our analysis of the factors underlying the fall in credit in East Asia is a model of excess liquid reserves. As is well known from the early literature surveyed by Baltensperger (1980), Santomero (1984) and Swank (1996), reserve management models deal with a bank's funding or liquidity risk. To manage this type of risk, and in deciding how much cash and other liquid assets they should hold, banks internalize the fact that they can draw funds from either the interbank market or the central bank in case of unexpected contingencies.

To begin with, consider the following simple model of reserve management (Baltensperger (1980)). Assume that there is only one representative bank whose deposits $D$ are given exogenously. The bank must decide upon the level of liquid, non-interest bearing reserve assets, $R$, and non-reserve assets, which take the form of illiquid loans, $L$. Its balance sheet is given by

$$
R+L=D .
$$

Reserves are necessary because the bank is exposed to liquidity risk. Deposit flows $u \in\left(u_{L}, u_{H}\right)$ occur randomly according to a density function $\phi=\Phi^{\prime}$. When the net outflow of cash exceeds the reserves, $u \geq R$, the bank must face illiquidity costs that are taken to be proportional to the reserve deficiency $\max (0, u-R)$. Put differently, in case of illiquidity the bank must borrow the missing reserves at a penalty rate $q$, with $q>r_{L}$, where $r_{L}$ is the interest rate on loans. Let $r_{D}$ denote the deposit rate; the bank's profit is thus

$$
\Pi=r_{L} L-r_{D} D-q \max (0, u-R),
$$

which implies that the bank's expected profit is

$$
\mathrm{E}(\Pi)=r_{L} L-r_{D} D-q \int_{R}^{u_{H}}(u-R) \phi(u) d u,
$$

that is, using (1):

$$
\mathrm{E}(\Pi)=\left(r_{L}-r_{D}\right) D-r_{L} R-q \int_{R}^{u_{H}}(u-R) \phi(u) d u .
$$


Assuming risk neutrality, the optimal level of reserves is determined so as to maximize expected profits. The necessary condition is thus: ${ }^{5}$

$$
\frac{\partial \mathrm{E}(\Pi)}{\partial R}=-r_{L}+q[1-\Phi(R)]=0,
$$

that is

$$
R^{*}=\Phi^{-1}\left(\frac{q-r_{L}}{q}\right) .
$$

Equation (4) implies that the marginal opportunity cost of holding an extra unit of reserves, $r_{L}$, is equated to the marginal reduction in liquidity costs. Optimal reserves decrease with the lending rate $r_{L}$ and increase with the penalty rate $q .{ }^{6}$

For our purpose here, we extend this simple model in several directions, following in part Prisman and Slovin (1986). Specifically, we account for required reserves, the link between the demand for cash and deposits, and output shocks. Suppose that the demand for loans, $L$, is negatively related to the lending rate and proportional to expected output, $Y^{e}$ :

$$
L=f\left(r_{L}\right) Y^{e}, \quad f^{\prime}<0 .
$$

Similarly, the supply of deposits by the public, $D$, is taken to be positively related to the deposit rate and proportional to expected output:

$$
D=g\left(r_{D}\right) Y^{e}, \quad g^{\prime}>0 .
$$

Suppose that agents determine $L$ and $D$ at the beginning of each period, before the realization of shocks to output. In addition, there is a demand for cash determined at the end of the period, following the realization of output and liquidity shocks. The bank is required to maintain liquid reserves in

\footnotetext{
${ }^{5}$ Because $\mathrm{E}(\Pi)$ is concave in $R$, the necessary condition is also sufficient.

${ }^{6}$ Moreover, if the distribution function of deposit flows can be approximated by a normal distribution, reserves can be shown to be proportional to the variance of deposit flows (see Baltensperger (1980)).
} 
proportion to its deposit base, at the interest rate $r$. Let $\theta$ denote the reserve requirement rate and $R$ total reserves; excess reserves, $Z$, are thus given by

$$
Z=R-\theta D
$$

that is, using (1) to eliminate $R$,

$$
Z=(1-\theta) D-L
$$

With $C$ denoting currency holdings, the equilibrium condition of the money market is given by

$$
C+D=k Y, \quad k>0,
$$

where $k$ is the reciprocal of velocity (assumed constant in what follows) and $Y$ realized output.

Suppose that the demand for cash is also proportional to realized output; specifically, let us assume that

$$
C=\frac{c}{1+c} k Y
$$

where $c=C / D$. We will assume in what follows that both output and $c k /(1+c)$ are random and given by

$$
Y=Y^{e}(1+\varepsilon), \quad \frac{c k}{1+c}=\Lambda(1+\xi),
$$

where $\varepsilon$ and $\xi$ are random shocks. Using (9) and (10), the demand for cash can be rewritten as

$$
C=\Lambda k Y^{e}(1+\varepsilon)(1+\xi) .
$$

For simplicity of exposition, suppose that the composite term $(1+\varepsilon)(1+$ $\xi)$, denoted $x$, is normally distributed with constant mean $\mu$ and constant variance $\sigma^{2}$ :

$$
x=(1+\varepsilon)(1+\xi) \sim N\left(\mu, \sigma^{2}\right) .
$$


To meet unexpected withdrawals (unanticipated demand for cash), the bank now can not only borrow at a penalty rate of $q$, as in the simple model presented above, but it may also use its excess reserves, $Z$. Using (7), the expected reserve deficiency is thus now given by

$$
E \max [0, C-((1-\theta) D-L)] .
$$

Using this result, together with (5), (6), (8), and (11), the bank's expected profits can be written as

$$
\Pi=\left[r_{L} f\left(r_{L}\right)-r_{D} g\left(r_{D}\right)\right] Y^{e}+r R-q E \max [0, C-((1-\theta) D-L)] .
$$

Assuming that the functions $f(\cdot)$ and $g(\cdot)$ are quasi-concave functions, the following propositions can be established:

Proposition $1 \mathrm{An}$ increase in the penalty rate increases deposits and lending rates, as well as excess reserves held by commercial banks.

Proposition 2 An increase in the volatility of output and liquidity shocks has ambiguous effects on the deposit rate, the lending rate, and excess reserves. If the initial level of the penalty rate is sufficiently high, an increase in volatility has a positive effect on all three variables.

Proposition 3 An increase in the reserve requirement rate unambiguously raises the lending rate and lowers excess reserves. If the degree of volatility is not too high, it also raises the deposit rate.

Proof of the results summarized in these propositions are provided in Appendix A. Proposition I implies that, for a high enough level of the penalty rate, excess reserves will exceed expected withdrawals, that is, $Z-\mu>0$. Under such conditions, Propositions 1, 2 and 3 can be combined to lead to the following demand function for excess reserves:

$$
Z=Z(\stackrel{+}{q}, \bar{\theta}, \stackrel{+}{\sigma})
$$

Equation (14) forms the basis of our empirical investigation. 


\section{Application to Thailand}

As noted in the introduction, the first step of our approach to assessing the extent to which the credit crunch that East Asian countries experienced in the immediate aftermath of their financial crisis was a supply or demandinduced phenomenon consists in estimating a demand function for excess liquid reserves by commercial banks. We apply our procedure to Thailand, a country where the contraction in credit was particularly severe and the increase in excess liquid assets held by the banking system very large (see below).

Equation (14) can be viewed as providing a static benchmark specification for desired, as opposed to actual, excess reserves. This benchmark specification is estimated in a fairly general dynamic setting to allow the model to capture the dynamics present in the data. ${ }^{7}$ Specifcally, the estimated demand equation for excess reserves by banks is expressed by the following autoregression, which accounts for contemporaneous as well as lagged effects:

$$
\begin{aligned}
\ln \left(\frac{E L}{D}\right)= & a_{1}(L) \ln \left(\frac{E L}{D}\right)+a_{2}(L) \ln \left(\frac{R R}{D}\right)+a_{3}(L) C V_{C / D}+a_{4}(L) C V_{Y / Y_{T}} \\
& +a_{5}(L) \ln \left(\frac{Y}{Y_{T}}\right)+a_{6}(L) r+v_{t},
\end{aligned}
$$

where $v_{t}$ is a well-behaved error term and $a_{j}(L)$ are lag polynomials, defined as

$$
\begin{gathered}
a_{1}(L)=a_{11} L+\ldots+a_{1 p} L^{p}, \\
a_{j}(L)=1+a_{j 1} L+\ldots+a_{j p} L^{p}, \quad j \geq 2,
\end{gathered}
$$

where $L$ is the lag operator. The dependent variable is the logarithm of the ratio of excess liquid assets held by commercial banks, $E L$, over total bank deposits, $D$. The regressors are lagged values of (the $\log$ of) the ratio of excess reserves to deposits; current and lagged values of (the log of) the ratio

\footnotetext{
${ }^{7}$ In the next section, this dynamic model is used to generate forecasts of the demand factors and the dynamic adjustment of movements in the demand for excess liquid reserves by commercial banks.
} 
of required liquid assets, $R R$, to total bank deposits, $D$; current and lagged values of the coefficient of variation of the cash-to-deposit ratio, $C / D$, and the deviation of output from trend, $Y / Y_{T}$; and current and lagged values of the discount rate, $r$, which corresponds to the penalty rate identified in (14). As noted by Van't Dack (1999), the discount window has been the last resort facility for banks and finance companies in Thailand. ${ }^{8}$

The above specification captures the main features of the model derived earlier. ${ }^{9}$ In particular, $\ln R R / D$ captures the impact of reserve requirements as derived in equation (14); $C V_{C / D}$ and $V_{Y / Y_{T}}$ account for the impact of volatility and liquidity risk, and thus the precautionary effect on the demand for reserves, as emphasized in (14). The penalty rate, $r$, is proxied by two interest rates. The first is the discount rate; as noted by Van't Dack (1999), the discount window has been the last resort facility for banks and finance companies in Thailand. The second is the money market rate which, to some extent, also reflected the cost of liquidity in the market. Notice also that the dynamics of adjustment of the demand of $E L / D$ is captured by the lagged values of $\ln (E L / D)$ in the regression. In addition, the regression includes $\ln \left(Y / Y_{T}\right)$ to proxy for changes in the demand for cash. A cyclical downturn, for instance, would lead banks to anticipate lower, transactionsrelated, demand for currency by the public and would therefore lead them to decrease their holdings of excess reserves. The lags account for the possibility

\footnotetext{
${ }^{8}$ Appendix B provides a more detailed description of these variables and identifies our data sources.

${ }^{9}$ The contemporaneous regressors included in the autoregression are generally exogenous to the commercial bank's demand for excess liquidity. This is the case for reserve requirements that are set by the authorities, the volatilities of $C / D$ and $Y / Y_{T}$ that reflect deposit holder's preferences and the volatility of the cyclical position, and the cyclical position of the economy $Y / Y_{T}$. Note that the quantity of (excess) liquidity and the penalty rate, as measured by the money market rate, may be jointly determined together with the supply of liquidity to commercial banks. This suggests that OLS estimates could be subject to simultaneity bias. However, note also that the estimation results obtained with the discount rate (which is more likely to be predetermined) are not very different, as discussed below. This suggests that if there is any simultaneity bias, it is likely to be small.
} 
of a gradual impact of funding costs and cyclical movements in output on the demand for excess reserves.

Figure 1 displays the evolution of some of the variables included in the regression equation during the period 1992-98. The first panel shows the evolution of the ratio of excess liquid assets (obtained as the difference between actual and required liquid assets) to bank deposits. ${ }^{10}$ The figure shows that excess liquid assets started to increase significantly well before the crisis (as early as late 1996), rising quite dramatically in the immediate aftermath of the currency and financial turmoil that began with the devaluation of the baht in July 1997. At the same time, the cyclical component of output turned sharply negative. The figure also shows that the money market rate fluctuated considerably during the period 1992-98 - exceeding at times the discount rate and falling well below it at other times. Finally, both the ratio of credit to the private sector to deposits, and the ratio of currency in circulation to deposits, increased at first and subsequently fell in the aftermath of the crisis.

Table 1 presents the summary of the estimation results of the autoregression using ordinary least squares based on monthly data and using the entire sample ending in September 1998. The table reports the sum of the coefficients and their standard errors of the lags of the regressors included in the estimation since individual coefficients in the autoregression are difficult to interpret directly. Conceptually, the sum of the coefficients are obtained by estimating the dynamic model and then setting $L=1$. Thus, the sum of the coefficients reported in the table correspond to the long-run effects once they have been appropriately scaled by: $1-a_{1}(1)$. In other words, Table 1 shows

\footnotetext{
${ }^{10}$ As noted in Sirivedhin (1998), prudential regulations in Thailand around the time of the crisis required commercial banks to hold liquid assets (averaged over a fortnight) of not less than seven percent of their deposit base; eligible assests included at least two percent non-interest-bearing deposits at the Bank of Thailand, a maximum of 2.5 percent cash in vault, and (making up the remainder) bonds issued by the government, approved state enterprises, specialized financial institutions or the Bank of Thailand.
} 
summarizes the long-run effects on the demand for $\ln (E L / D) .{ }^{11}$ The more traditional method to examine long-run effects, cointegration analysis, is not carried out here because of the short time period spun by the data sample. ${ }^{12}$ Moreover for the purpose at hand of providing a empirical framework to generate forecasts of $\ln (E L / D)$ within the framework provided by equation (14), a reduced from autoregression will contain all of the information in the data without taking a stand on critical issues such as the number of unit roots and cointegrating vectors in the empirical model based on a fairly short sample.

Consider the main empirical results when the penalty rate, $r$, is the discount rate (panel A, Table 1). The estimation results are in general consistent with our priors although the precision (ratio of the coefficient to its standard error) with which these effects are measured is low. ${ }^{13}$ In particular, $\ln (R R / D)$ appears to have a negative impact on $\ln (E L / D)$ as expected, the volatility of $\ln (C / D)$, as proxied by $C V_{C / D}$, tends to increase $\ln (E L / D)$, and the effect of an increase in the penalty rate, $r$, is to increase $\ln (E L / D)$. The sum of the coefficients on the cyclical component of output on the demand of $E L / D$ confirms the role that cyclical conditions have on $\ln (E L / D)$, and in contrast these effects are precisely measured. Note also that these results are not affected when the volatility of $C / D$ and/or $Y / Y_{T}$ is dropped from the regression as evidence by columns 2 and 3 . However, the volatility of $Y / Y_{T}$, as proxied by $C V_{Y / Y_{T}}$, is incorrectly signed and not measured precisely. It is not clear what is behind this implied perverse effect of the volatility of $Y / Y_{T}$, although the increase in the precision of the measured effect of $\ln \left(Y / Y_{T}\right)$ when $C V_{Y / Y_{T}}$ is dropped from the regression (column 2) is

\footnotetext{
${ }^{11}$ The results presented in Table 1 correspond to $p=3$. Where appropriate the robustness of these results is discussed for $p=6$; the model is unstable for $p>6$.

${ }^{12}$ See Civcir and Parikh (1995) for an estimation based on cointegration analysis for credit and demand for reserves.

${ }^{13}$ These results are reasonably robust, and qualitatively do not change when the model is estimated with $p=6$. The only effect that is somewhat less robust is the effect of the penalty rate on excess reserves, which is positive (as in Table 1) only when $C V_{C / D}$ and $C V_{Y / Y_{T}}$ are included in the regression, that is, columns (1) and (4).
} 
suggestive of the difficulty in separating the effects of the output cycle from the volatility in the output cycle. Finally, the sum of the coefficients and the precision with which the effect of lagged $E L / D$ is measured is suggestive of significant dynamic adjustment by commercial banks demand for excess liquidity. Because qualitatively the results obtained when the penalty rate, $r$, is proxied by the money market rate (columns 4-6, panel $\mathrm{B}$, Table 1) are fairly robust, we discuss below refer only the estimates shown in Panel A. ${ }^{14}$

Despite the turbulence associated with the Asian crisis in 1997-98, there is very little evidence that this translated into instability in the estimated parameters. The tests proposed by Andrews (1993) were used to examine the stability of the estimates because the date of the potential change in the parameters is unknown. The test boils down to choosing the largest statistic from a series of standard Chow tests, and because the break point is unknown the distribution of the max-Chow is non-standard. The Chow tests were performed from the beginning of 1995 to the end of 1997, and the max-Chow are 74.13, 52.34 and 54.74 respectively for equations 1 through 3 . At standard significance levels, these tests reject stability in equation, but not in equations 2 and 3 (see the tables in Andrews (1993)). This stability result is important because it implies that the difference between the preand post-crisis behavior of excess liquid assets, as predicted by the model, can only reflect changes in the behavior of the determinants of the demand for these assets (as captured in the regression model), as opposed to changes in the parameters characterizing the behavior of commercial banks.

Figure 2 shows the behavior of actual and dynamic forecasts of the ratio of excess liquid assets to deposits, for each of the three specifications in Table 1. ${ }^{15}$ The dynamic forecasts are calculated in-sample beginning in January

\footnotetext{
${ }^{14}$ In general, the signs of the estimated coefficients remains unchanged; the main differences are limited to the size of some of the coefficients. In particular, the effect of $r$ $\left(C V_{C / D}\right)$ in equation (2) increases (decreases) dramatically, from about 0.22 (1.17) to 2.1 $(0.14)$. Also, the effect of $\ln (R R / D)$ falls somewhat.

${ }^{15}$ Details of the calculations of the dynamic forecasts are specified in the next section.
} 
1994 and are calculated up to end of the sample period, October 1998. With the exception of the forecasts for equation (1), the model does a reasonable job of capturing the increase in the ratio of excess liquid assets during the early part of 1996. It is interesting that the forecasts for equations (2) and (3) track the data fairly well, suggesting that the volatility of the ratio of cash to deposits, $C V_{C / D}$, does not appear to be the leading factor explaining the increases in the ratio of excess liquid assets.

\section{Dynamic Forecasts}

The second step of our approach to assessing the existence of a credit crunch in Thailand in the aftermath of its economic and financial crisis consists in establishing dynamic forecasts for the period July 1997 onward and assessing whether the forecast errors from the predictions of the regression model of excess liquid assets estimated in the previous section (that is, the difference between actual and projected values) are small enough to be consistent with the predicted path of reserves, or on the contrary large enough to be viewed as indicators of "involuntary" accumulation of excess reserves-which would be more consistent with a demand-induced slowdown in credit.

Dynamic forecasts are obtained by using the estimates underlying the results in column 3 panel A, Table 1, our preferred specification. Specifically, the dynamic forecasts are obtained as the expected value of the empirical model:

$$
\begin{aligned}
\mathrm{E}\left[\ln \left(\frac{E L}{D}\right)_{t+h} \quad \mid \Omega_{t}\right]=\hat{a}_{1}(L) \ln \left(\frac{E L}{D}\right)_{t+h}+\hat{a}_{2}(L) \ln \left(\frac{R R}{D}\right)_{t+h} \\
+\hat{a}_{5}(L) \ln \left(\frac{Y}{Y_{T}}\right)_{t+h}+\hat{a}_{6}(L) r_{t+h},
\end{aligned}
$$

where $\Omega_{t}$ is a vector containing the information set used to make the forecasts $h$-periods ahead, specifically

$$
\Omega_{t}=\left[\mathrm{E}_{t-s}\left[\ln (E L / D)_{t-s+1}\right], \ln (R R / D)_{t+j}, \ln \left(Y / Y_{T}\right)_{t+j}, r_{t+j}\right]
$$


with $s=1,2, \ldots, p$, and $j=0,1, \ldots, h$; and a "^ indicates estimated values of the corresponding lag polynomials. Thus, for forecasts of the first month, July 1997, the forecast is calculated by taking the actual values of $\ln (E L / D)$ in June 1997 and previous months, and the actual values of the other regressors $\left(\ln (R R / D), \ln \left(Y / Y_{T}\right)\right.$, and $\left.r\right)$ in July and their lagged values. Forecasts for subsequent months are obtained by taking the forecasted value of $\ln (E L / D)$ for the previous month and the actual values of the other regressors, so that previous forecasts of $\ln (E L / D)$ feed into its subsequent forecasts. The standard errors of the forecasts are obtained ignoring the sampling variance, as is standard practice (see Granger and Newbold (1986, p. 158), and Doan (1996, pp. 14-76)).

Figure 3 shows the behavior of the observed $\ln (E L / D)$ and the dynamic forecasts for each of the three specifications in Table 1 of the ratio of excess liquid assets to deposits for the period July 1997 to October 1998, together with one- (upper panel) and two-standard error bands (lower panel). Excluding the results for equation (1), what comes out clearly from the dynamic forecasts in Figure 3 that both in the immediate aftermath of the crisis and subsequently, actual values are about what could be expected from the model and do not seem to diverge dramatically what could be expected from forecasts of the model and their associated error. For equation (1), however, actual values diverge from their forecasted values; judging from the onestandard error band this occurs in January/February 1998, whereas with a two-standard error band this occurs a couple of months latter. After that actual values of $\ln (E L / D)$ grow increasingly, well outside the error bands.

In sum, within the framework of our general hypothesis it appears that the persistent increase in excess reserve holdings by commercial banks following the collapse of the baht appears to have reflected a supply-side phenomenon, that is, higher excess liquid assets consistent with bank behavior. This, of course, is conditional on our claim that our regression model captures well the higher perceived degree of uncertainty or risk of default in the aftermath 
of the crisis.

\section{Summary and Concluding Remarks}

The purpose of this paper has been to propose an alternative approach to examining the extent to which the fall in credit that characterized most crisisstricken countries in East Asia reflected a credit crunch, that is, increased incidence of credit rationing by banks. We began by developing a demand function for excess reserves (or liquid assets) by commercial banks that captured, in particular, the impact of reserve requirements, funding costs, and precautionary motives related to liquidity risk and output volatility. We then estimated a dynamic version of the model and showed that the stability of the model cannot be rejected using standard tests. We then used the model to establish dynamic projections for the post-crisis period (July 1997 to October 1998). Our general assumption is that if actual values of excess reserves are within one- or two-standard error bands, the observed reduction in credit is consistent with a supply-side phenomenon. On the contrary, if actual values are outside the errors bands, this can be construed as evidence of "involuntary" accumulation of excess reserves; the slowdown in credit may thus more likely reflect a reduction in the demand for loans-possibly reflecting firms' perceived weaknesses in future demand for their products.

Our results suggest that the fall in bank lending in Thailand seems to have been a reflection of a supply phenomenon, as argued by those who believe in the credit crunch hypothesis. Overall, therefore, our results are consistent with those obtained by Ito and Pereira da Salva (1999) and with those of Domaç and Ferri (1999a), whose study indicates that small and mediumsized firms in Thailand faced binding constraints in accessing credit markets in the aftermath of the crisis. It would be useful to apply the methodology developed here to other crisis-stricken countries in East Asia; whether this would prove fruitful or not remains to be seen. As noted by Domaç and Ferri 
$(1999 b)$, in particular, in Indonesia the ratio of excess reserves to deposits did not display the same sharp increase observed in Thailand. 


\section{Appendix A \\ Derivation of Propositions 1 to 3}

Assuming that the functions $f(\cdot)$ and $g(\cdot)$ are quasi-concave, the results summarized in Propositions land 2 can be written as

$$
\begin{gathered}
\frac{d r_{L}}{d q}>0, \quad \frac{d r_{D}}{d q}>0, \quad \frac{d Z}{d q}>0, \\
\operatorname{sg}\left[\frac{d r_{L}}{d \sigma}\right]=\operatorname{sg}\left[\frac{d r_{D}}{d \sigma}\right]=\operatorname{sg}\left[\frac{d Z}{d \sigma}\right]=\operatorname{sg}(Z-\mu) .
\end{gathered}
$$

To establish these results, we begin by rewriting (13), with $Y^{e}$ normalized to unity, and using (1) to eliminate $R$, as

$$
\begin{gathered}
\Pi=r_{L} f\left(r_{L}\right)-r_{D} g\left(r_{D}\right) \\
+r\left[f\left(r_{L}\right)-g\left(r_{D}\right)\right]-q E \max [0, C-((1-\theta) D-L)] .
\end{gathered}
$$

Assuming, as indicated in the text, that $x$ is normally distributed with constant mean $\mu$ and constant variance $\sigma^{2}$, this expression can be rewritten as

$$
\begin{gathered}
\Pi=r_{L} f\left(r_{L}\right)-r_{D} g\left(r_{D}\right) \\
+r\left[f\left(r_{L}\right)-g\left(r_{D}\right)\right]-q \int_{(1-\theta) D-L}^{\infty}\{x-((1-\theta) D-L)\} \phi(x) d x,
\end{gathered}
$$

where $\phi$ is the density function of $x$ (assumed normal). Maximizing this expression with respect to the deposit and lending rates yields the first-order conditions

$$
\begin{gathered}
\Pi_{r_{L}}=\left(r_{L}-r\right) f^{\prime}+f-q f^{\prime}\left\{1-\Phi\left(\frac{(1-\theta) D-L-\mu}{\sigma}\right)\right\}=0, \\
\Pi_{r_{D}}=\left(r-r_{D}\right) g^{\prime}-g+q(1-\theta) g^{\prime}\left\{1-\Phi\left(\frac{(1-\theta) D-L-\mu}{\sigma}\right)\right\}=0,
\end{gathered}
$$

where $\Phi$ is the cumulative distribution function of $x$. 
Let $\varepsilon_{D}=r_{D} g^{\prime} / g$ and $\varepsilon_{L}=-r_{L} f^{\prime} / f$ denote, respectively, the elasticities of the supply of deposits by the public and the demand for loans. The above expressions can be rewritten as

$$
\begin{gathered}
r_{L}-\varepsilon_{L}\left(r_{L}-r\right)+q \varepsilon_{L}(1-\Phi)=0, \\
\varepsilon_{D}\left(r-r_{D}\right)-r_{D}+q \varepsilon_{D}(1-\theta)(1-\Phi)=0,
\end{gathered}
$$

which imply that

$$
r_{L}=\frac{r+q(1-\Phi)}{1-\varepsilon_{L}^{-1}}, \quad r_{D}=\frac{r+q(1-\theta)(1-\Phi)}{1+\varepsilon_{D}^{-1}} .
$$

These expressions indicate, in particular, that an increase in the penalty rate $q$ raises both the deposit and lending rates to an extent that is inversely related to the elasticity of supply of deposits and demand for loans.

Let us assume that the quantity $r_{L} f\left(r_{L}\right)-r_{D} g\left(r_{D}\right)+r\left[g\left(r_{D}\right)-f\left(r_{L}\right)\right]$ is quasi-concave in $r_{L}$ and $r_{D}$, so that ${ }^{16}$

$$
f f^{\prime \prime}-2\left(f^{\prime}\right)^{2}<0, \quad g g^{\prime \prime}-2\left(g^{\prime}\right)^{2}<0 .
$$

Under these assumptions, it can indeed be established that both $d r_{L} / d q$ and $d r_{D} / d q$ are positive. To do so, note that

$$
\Pi_{r_{L} r_{L}}=\left(r_{L}-r\right) f^{\prime \prime}+2 f^{\prime}-q f^{\prime \prime}(1-\Phi)-q \phi \frac{\left(f^{\prime}\right)^{2}}{\sigma}
$$

\footnotetext{
${ }^{16}$ Let $h\left(r_{L}, r_{D}\right)$ be defined as

$$
h\left(r_{L}, r_{D}\right)=r_{L} f\left(r_{L}\right)-r_{D} g\left(r_{D}\right)+r\left[g\left(r_{D}\right)-f\left(r_{L}\right)\right] .
$$

We have

$$
\begin{gathered}
h_{r_{L}}=f+\left(r_{L}-r\right) f^{\prime} \\
\dot{h}_{r_{L} r_{L}}=2 f^{\prime}+r_{L} f^{\prime \prime}-r f^{\prime \prime}=2 f^{\prime}+\left(r_{L}-r\right) f^{\prime \prime}
\end{gathered}
$$

so that $h_{r_{L} r_{L}}<0$ at $h_{r_{L}}=0$. The latter condition, which is equivalent to $f+\left(r_{L}-r\right) f^{\prime}=0$, implies that $r_{L}-r=-f / f^{\prime}$. Substituting this result in the definition of $h_{r_{L} r_{L}}$ gives, at $h_{r_{L}}=0$,

$$
2 f^{\prime}-f^{\prime \prime} f / f^{\prime}<0
$$
}

or equivalently $f f^{\prime \prime}-2\left(f^{\prime}\right)^{2}<0$. Similar derivations yield the second result in (A1). 


$$
\begin{gathered}
\Pi_{r_{D} r_{D}}=\left(r-r_{D}\right) g^{\prime \prime}-2 g^{\prime}+q(1-\theta)(1-\Phi) g^{\prime \prime}-q \phi \frac{\left[(1-\theta) g^{\prime}\right]^{2}}{\sigma} \\
\Pi_{r_{L} r_{D}}=\frac{q f^{\prime} \phi(1-\theta) g^{\prime}}{\sigma}<0 .
\end{gathered}
$$

The effect of $q$ on $r_{L}$ can be assessed from

$$
\left[\begin{array}{ll}
\Pi_{r_{L} r_{L}} & \Pi_{r_{L} r_{D}} \\
\Pi_{r_{L} r_{D}} & \Pi_{r_{D} r_{D}}
\end{array}\right]\left[\begin{array}{l}
d r_{L} / d q \\
d r_{D} / d q
\end{array}\right]=\left[\begin{array}{c}
(1-\Phi) f^{\prime} \\
-(1-\theta)(1-\Phi) g^{\prime}
\end{array}\right]
$$

Let $\Delta$ be

$$
\Delta=\Pi_{r_{L} r_{L}} \Pi_{r_{D} r_{D}}-\Pi_{r_{L} r_{D}}^{2} .
$$

$\Delta$ is positive from the second-order conditions for profit maximization. We therefore have

$$
\frac{d r_{L}}{d q}=\frac{-(1-\Phi)}{|\Delta|}\left\{-f^{\prime}\left[\Gamma-q \phi \frac{\left[(1-\theta) g^{\prime}\right]^{2}}{\sigma}\right]-\frac{q \phi f^{\prime}\left[(1-\theta) g^{\prime}\right]^{2}}{\sigma}\right\}
$$

where $\Gamma$ is defined as

$$
\Gamma=\left(r-r_{D}\right) g^{\prime \prime}-2 g^{\prime}+q(1-\theta)(1-\Phi) g^{\prime \prime} .
$$

The above expression can be rewritten as

$$
\frac{d r_{L}}{d q}=\frac{f^{\prime}(1-\Phi) \Gamma}{|\Delta|}
$$

which implies that, because $f^{\prime}<0$, that

$$
\operatorname{sg}\left[\frac{d r_{L}}{d q}\right]=-\operatorname{sg}[\Gamma] .
$$

To show that $d r_{L} / d q>0$ requires therefore showing that $\Gamma<0$. To do so, note first that quasi-concavity of $g(\cdot)$ implies that $g^{\prime \prime}<2\left(g^{\prime}\right)^{2} / g$, so that

$$
\Gamma<\left(r-r_{D}\right) g^{\prime \prime}-\frac{g^{\prime \prime} g}{g^{\prime}}+q(1-\theta)(1-\Phi) g^{\prime \prime}
$$


or equivalently

$$
\Gamma<\frac{g^{\prime \prime}}{g^{\prime}}\left\{\left(r-r_{D}\right) g^{\prime}-g+q g^{\prime}(1-\theta)(1-\Phi)\right\} .
$$

From the first-order conditions for profit maximization, the quantity $(r-$ $\left.r_{D}\right) g^{\prime}-g$ is equal to $-q(1-\theta)(1-\Phi) g^{\prime}$. Substituting this result on the right-hand side of the above expression implies that the term in brackets is zero and therefore that $\Gamma<0$. Thus, from (A4), $d r_{L} / d q>0$.

The effect of $q$ on $r_{D}$ can be assessed in a similar manner. Specifically, it can be established that

$$
\begin{gathered}
\frac{d r_{D}}{d q}=\frac{-(1-\Phi)}{|\Delta|}\left\{(1-\theta) g^{\prime}\left[\left(r_{L}-r\right) f^{\prime \prime}+2 f^{\prime}-q f^{\prime \prime}(1-\Phi)-\frac{q \phi\left(f^{\prime}\right)^{2}}{\sigma}\right]\right. \\
\left.+q\left(f^{\prime}\right)^{2} \phi \frac{(1-\theta) g^{\prime}}{\sigma}\right\}
\end{gathered}
$$

or equivalently

$$
\frac{d r_{D}}{d q}=\frac{-(1-\Phi)(1-\theta) g^{\prime}}{|\Delta|}\left\{\left(r_{L}-r\right) f^{\prime \prime}+2 f^{\prime}-q f^{\prime \prime}(1-\Phi)\right\}
$$

Thus,

$$
\operatorname{sg}\left[\frac{d r_{D}}{d q}\right]=-\operatorname{sg}\left[\left(r_{L}-r\right) f^{\prime \prime}+2 f^{\prime}-q f^{\prime \prime}(1-\Phi)\right] .
$$

Given the above definitions,

$$
\left(r_{L}-r\right) f^{\prime \prime}+2 f^{\prime}-q f^{\prime \prime}(1-\Phi)=-\frac{f^{\prime \prime}}{f^{\prime}}\left\{-\left(r_{L}-r\right) f^{\prime}-2 \frac{\left(f^{\prime}\right)^{2}}{f^{\prime \prime}}+q f^{\prime}(1-\Phi)\right\} .
$$

From the first-order conditions for profit maximization, the term in brackets on the right-hand side of this expression is also equal to

$$
-\frac{f^{\prime \prime}}{f^{\prime}}\left\{-\left(r_{L}-r\right) f^{\prime}-2 \frac{\left(f^{\prime}\right)^{2}}{f^{\prime \prime}}+\left(r_{L}-r\right) f^{\prime}+L\right\}
$$

which is equal to

$$
-\frac{f^{\prime \prime}}{f^{\prime}}\left\{L-2 \frac{\left(f^{\prime}\right)^{2}}{f^{\prime \prime}}\right\}=-\frac{1}{f^{\prime}}\left\{f \cdot f^{\prime \prime}-2\left(f^{\prime}\right)^{2}\right\}<0 .
$$


Thus, from (A5), $d r_{D} / d q>0$.

The effect of $q$ on excess reserves is straightforward; it can be established that, given the above results,

$$
\frac{d Z}{d q}=(1-\theta) g^{\prime} \frac{d r_{D}}{d q}-f^{\prime} \frac{d r_{L}}{d q}>0
$$

Let us establish the effects of a change in $\sigma$. From a system similar to (A2), we can establish that

$$
\left[\begin{array}{l}
d r_{L} / d \sigma \\
d r_{D} / d \sigma
\end{array}\right]=\Delta^{-1}\left[\begin{array}{c}
q f^{\prime} \phi(Z-\mu) / \sigma^{2} \\
-q(1-\theta) g^{\prime} \phi(Z-\mu) / \sigma^{2}
\end{array}\right]
$$

which implies that

$$
\left[\begin{array}{l}
d r_{L} / d \sigma \\
d r_{D} / d \sigma
\end{array}\right]=\frac{q \phi(Z-\mu)}{\Delta \sigma^{2}}\left[\begin{array}{c}
f^{\prime} \\
-(1-\theta) g^{\prime}
\end{array}\right]
$$

Thus

$$
\frac{d r_{L}}{d \sigma}=\frac{q \phi(Z-\mu)}{\Delta \sigma^{2}} f^{\prime} \Gamma
$$

This result implies that, given the sign assumptions, and given that, as shown above, $\Gamma<0$,

$$
\operatorname{sg}\left[\frac{d r_{L}}{d \sigma}\right]=\operatorname{sg}(Z-\mu) .
$$

It can also be established that

$$
\operatorname{sg}\left[\frac{d r_{D}}{d \sigma}\right]=\operatorname{sg}\left[\frac{d Z}{d \sigma}\right]=\operatorname{sg}(Z-\mu)
$$

Finally, let us consider the effect of a change in the reserve requirement rate, $\theta$, on interest rates and excess reserves, as summarized in Proposition 3. It can be shown that, in a manner analogous to (A2),

$$
\left[\begin{array}{ll}
\Pi_{r_{L} r_{L}} & \Pi_{r_{L} r_{D}} \\
\Pi_{r_{L} r_{D}} & \Pi_{r_{D} r_{D}}
\end{array}\right]\left[\begin{array}{l}
d r_{L} / d \theta \\
d r_{D} / d \theta
\end{array}\right]=\left[\begin{array}{c}
q \phi f^{\prime} g / \sigma \\
-q \phi(1-\theta) g^{\prime} g / \sigma+q(1-\Phi) g^{\prime}
\end{array}\right] .
$$

This implies that, using the definition of $\Gamma$ given above in (A3):

$$
\frac{d r_{L}}{d \theta}=\frac{q \phi f^{\prime} g \Gamma}{\sigma|\Delta|}-q(1-\Phi) g^{\prime} \frac{q \phi(1-\theta) f^{\prime} g^{\prime}}{\sigma|\Delta|}
$$


from which it can be verified that, given that $\Gamma<0, d r_{L} / d \theta>0$.

We also have

$$
\frac{d r_{D}}{d \theta}=\frac{q^{\prime} f^{\prime} g \Gamma}{\sigma|\Delta|}+\frac{q(1-\Phi) g^{\prime}}{|\Delta|} \Pi_{r_{L} r_{L}}
$$

that is

$$
\frac{d r_{D}}{d \theta}=-\frac{q g \Gamma}{\sigma|\Delta|}\left\{-f^{\prime} \Gamma-\frac{g^{\prime} \sigma(1-\Phi)}{g}\left(\left(r_{L}-r\right) f^{\prime \prime}+2 f^{\prime}-q f^{\prime \prime}(1-\Phi)-\frac{q \phi f^{\prime 2}}{\sigma}\right)\right\} .
$$

It can be established that the term in parentheses on the right-hand side is equivalent to

$$
\frac{-f^{\prime}\left(g^{\prime \prime} g-2\left(g^{\prime}\right)^{2}\right.}{g^{\prime}}-\frac{\sigma(1-\Phi) g^{\prime}}{g}\left\{\frac{2 f^{\prime 2}-f^{\prime \prime} f}{f^{\prime}}-\frac{q \phi\left(f^{\prime}\right)^{2}}{\sigma}\right\} .
$$

Given the assumptions specified given above, the first term is negative whereas the second is positive. If the degree of volatility is not too high (that is, if $\sigma$ is small) the first term will dominate and, given that $\Gamma<0$, we will have $d r_{D} / d \theta>0$.

Finally, to assess the impact of $\dot{\theta}$ on $Z$, note that from the first-order conditions,

$$
\left(r_{L}-r\right) f^{\prime}+f=q f^{\prime}\left\{1-\frac{\Phi(Z-\mu)}{\sigma}\right\}
$$

which gives

$$
\frac{1}{q}\left\{r_{L}-r+\frac{f}{f^{\prime}}\right\}=1-\frac{\Phi(Z-\mu)}{\sigma} .
$$

This expression implies that

$$
\operatorname{sg}\left[\frac{d Z}{d \theta}\right]=-\operatorname{sg}\left[\frac{d r_{L}}{d \theta}+\frac{d\left(f / f^{\prime}\right)}{d \theta}\right] .
$$

The expression in brackets on the right-hand side can be rewritten as

$$
\frac{d r_{L}}{d \theta}+\frac{d\left(f / f^{\prime}\right)}{d \theta}=\frac{d r_{L}}{d \theta}+\frac{f^{\prime}}{f^{\prime}} \frac{d r_{L}}{d \theta}-\frac{f}{\left(f^{\prime}\right)^{2}} f^{\prime \prime} \frac{d r_{L}}{d \theta}
$$

so that

$$
\frac{d r_{L}}{d \theta}+\frac{d\left(f / f^{\prime}\right)}{d \theta}=\left\{2-\frac{f}{\left(f^{\prime}\right)^{2}} f^{\prime \prime}\right\} \frac{d r_{L}}{d \theta}=\left\{\frac{2\left(f^{\prime}\right)^{2}-f^{\prime \prime} f}{\left(f^{\prime}\right)^{2}}\right\} \frac{d r_{L}}{d \theta} .
$$

As shown earlier, $d r_{L} / d \theta>0$; thus, $d Z / d \theta<0$. 


\section{Appendix B Data Sources and Definitions}

The data used in this study are at a monthly frequency and cover the period January 1992 to October 1998. The variables are defined and measured as follows.

- Excess liquid assets, $E L$, are from Bank of Thailand.

- Required liquid assets, $R R$, are from Bank of Thailand.

- Total deposits, $D$, are the sum of demand, time, and savings deposits in deposit money banks. The data are from International Financial Statistics (IFS), sum of line 24 and 25.

- Currency, $C$, is defined as currency in circulation outside of deposit money banks. Data are from IFS (line 14a).

- Manufacturing output, $Y$, is a seasonally-adjusted index, with 1990 as a base period. The data are from the International Monetary Fund.

- The trend component of manufacturing output, $Y_{T}$, is the quadratic trend which is equal to the fitted value obtained by regressing $Y$ on constant term, time and time squared variables.

- The discount rate, $r$ is from IFS (line 60).

- The coefficient of variation for the $\log$ of currency to deposit ratio, $C V[\ln (C / D)]$, and the log of manufacturing output to trend component ratio, $C V\left[\ln \left(Y / Y_{T}\right)\right]$ are equal to the standard deviation of the specified variable divided by the average of it for 3 leads and lags, centered on the current period. 


\section{References}

Andrews, D. W., "Tests for Parameter Instability and Structural Change with Unknown Change Point," Econometrica, 61 (- 1993), 821-56.

Agénor, Pierre-Richard, and Joshua Aizenman, "Contagion and Volatility with Imperfect Credit Markets," IMF Staff Papers, 45 (June 1998), 207-35.

Alba, Pedro, Amar Bhattacharya, Stijn Claessens, Swati Ghosh, and Leonardo Hernandez, "The Role of Macroeconomic and Financial Sector Linkages in East Asia's Financial Crisis," in Financial Crises: Contagion and Market Volatility, ed. by Pierre-Richard Agénor, Marcus Miller, David Vines, and Axel Weber (Cambridge University Press: 1999).

Civçir, Irgan, and Ashok Parikh, "Multivariate Cointegration Approach to the Determination of Reserves and Bank Credit: A Case Study of Turkey," Bulletin of Economic Research, 47 (January 1995), 55-76.

Doan, Thomas, Rats: User's Manual, Version 4.0, Estima (Evanston, Ill.: 1996).

Dollar, David, and Mary Hallward-Driemeier, "Crisis, Adjustment, and Reform in Thai Industry," unpublished, the World Bank (November 1998).

Domaç, Ilker, and Giovanni Ferri, "The Credit Crunch in East Asia: Evidence from Field Findings on Bank Behavior and Policy Issues," unpublished, the World Bank (November 1999a).

_-, "Did Financial Shocks Disproportionately Hit Small Businesses in Asia? Evidence from Malaysia and the Republic of Korea," unpublished, the World Bank (November 1999b).

Dwor-Frecaut, Dominique, Mary Hallward-Driemeier, and Francis Colaco, "Corporate Credit Needs and Corporate Governance," unpublished, the World Bank (March 1999).

Ghosh, Swati, and Atish Ghosh, "East Asia in the Aftermath-Was There a Crunch?" unpublished, the World Bank (October 1999).

Grange, Clive W., and Paul Newbold, Forecasting Economic Time Series, Academic Press, 2nd ed. (New York: 1986).

Ito, Takatoshi, and Luis Pereira da Silva, "The Credit Crunch in Thailand during the 1997-98 Crisis," unpublished, the World Bank (November 1999).

Jaffee, Dwight, and Joseph Stiglitz, "Credit Rationing," in Handbook of Monetary Economics, Vol. II, ed. by Benjamin M. Friedman and Frank H. Hahn, North Holland (Amsterdam: 1990).

Prisman, Eliezer Z., and Myron B. Slovin, "General Model of the Banking Firm under Conditions of Monopoly, Uncertainty, and Recourse," Journal of 
Monetary Economics, 17 (March 1986), 293-304.

Nautz, Dieter, "Banks' Demand for Reserves when Future Monetary Policy is Uncertain," Journal of Monetary Economics, 42 (August 1998), 161-83.

Santomero, Anthony M., "Modelling the Banking Firm: A Survey," Journal of Money, Credit, and Banking 16 (- 1984), 576-602 and 696-712.

Sirivedhin, Tanya, "Financial Reform and the Monetary Transmission Mechanism: The Case of Thailand," in The Transmission of Monetary Policy in Emerging Market Economies, Policy Paper No. 3, Bank for International Settlements, Basle ((january 1998).

Swank, Job, "Theories of the Banking Firm: A Review of the Literature," Bulletin of Economic Research, 48 (July 1996), 1-35.

Van't dack, Jozef, "Implementing Monetary Policy in Emerging Market Economies: An Overview of Issues," in Monetary Policy Operation Procedures in Emerging Market Economies, Policy Paper No. 5, Bank for International Settlements (Basle: 1999).

Walsh, Carl E., Monetary Theory and Policy, MIT Press (Cambridge, Mass.: 1998). 
Figure 6

Developing Countries: Consumer Price Inflation and Inflation Volatility (Averages over 1981-98)

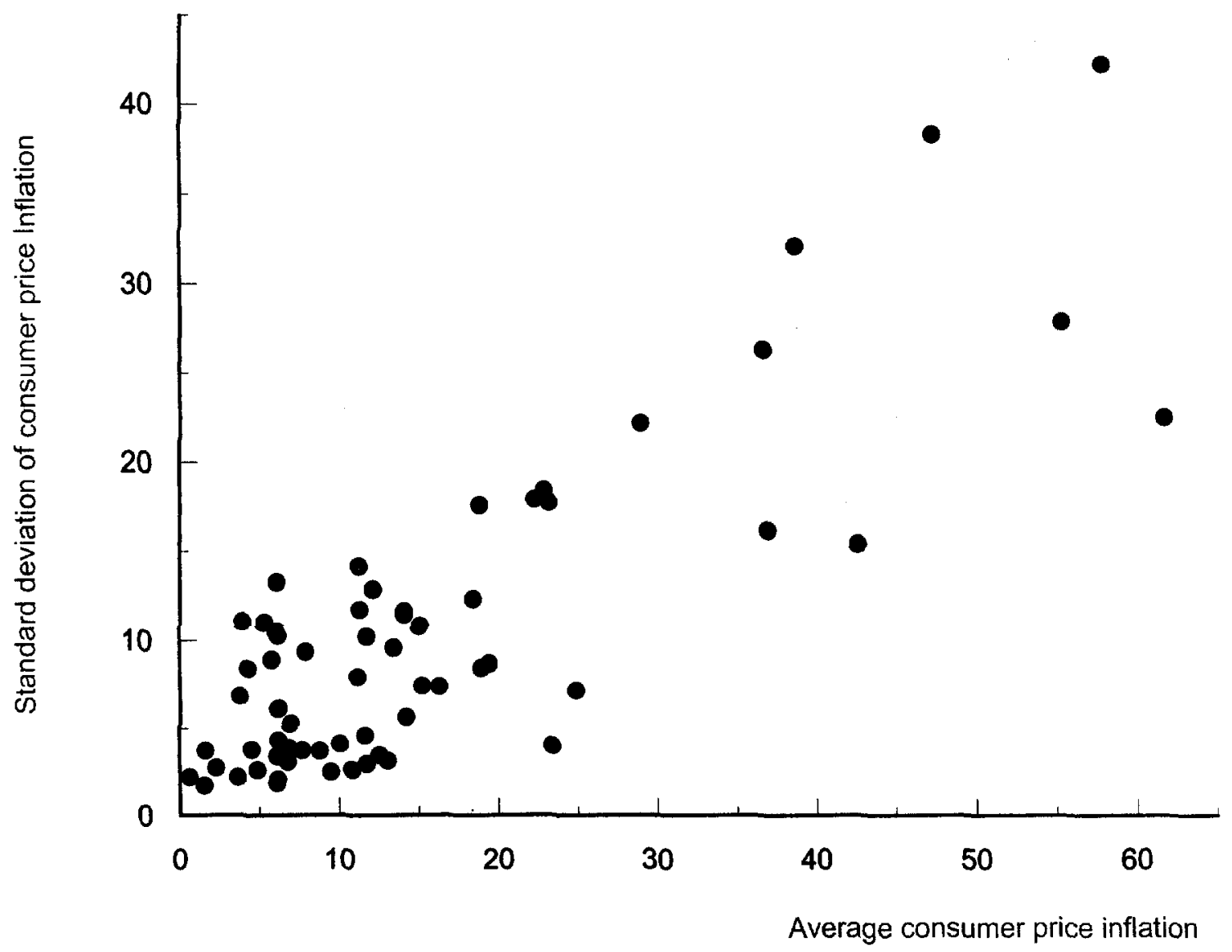

Note: For the list of countries represented in this figure, see the note to Figure 5.

Source: World Bank. 
Figure 1

Thailand: Macroeconomic Indicators, January 1992 - October 1998
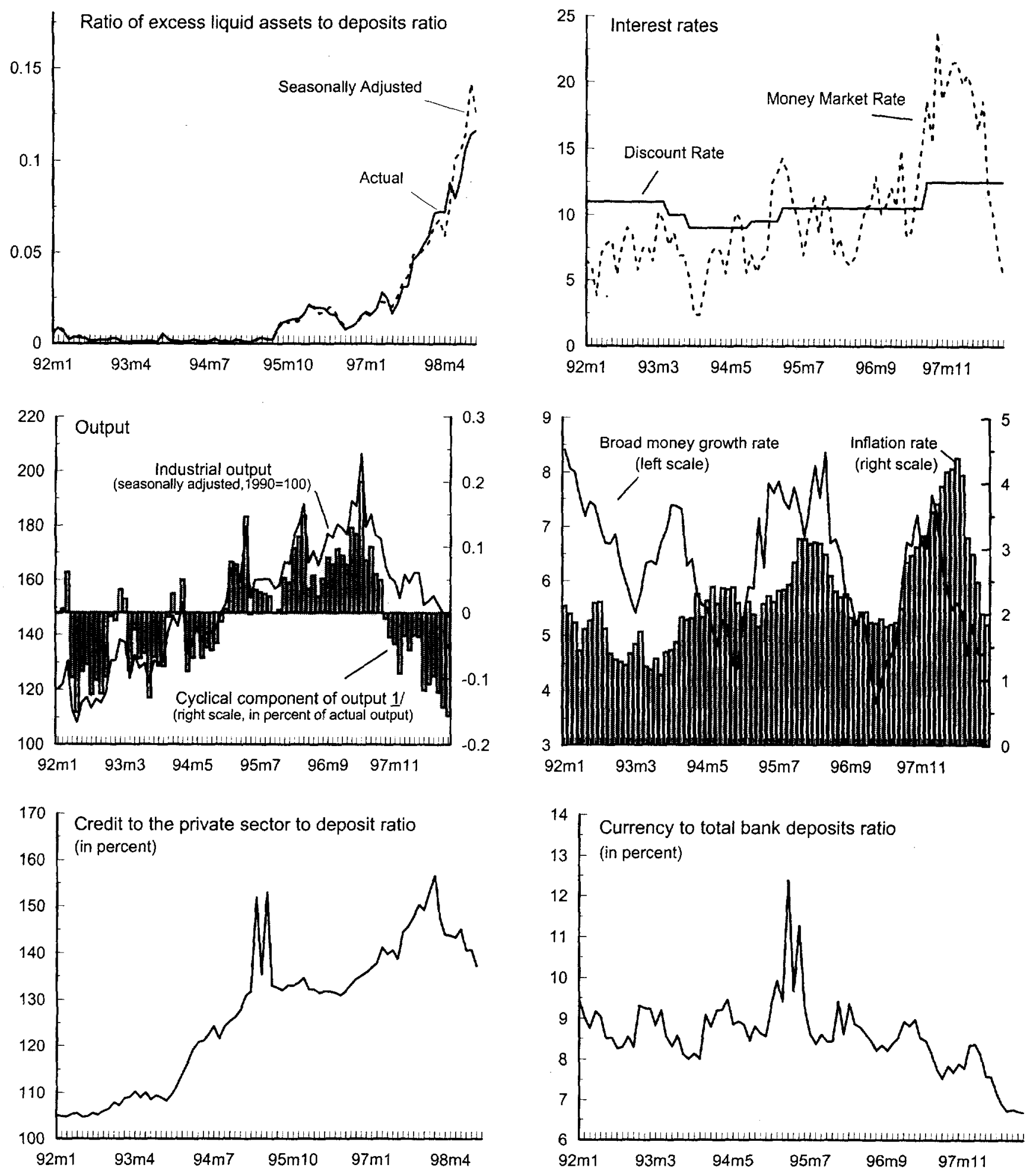

Source: International Monetary Fund, International Financial Statistics and Bank of Thailand 1/ Calculated as the difference between actual output and a quadratic trend. 
Figure 2

Predicted and Actual Values of Excess Liquid Assets to Deposits Ratio

(Dynamic simulation: January 1994 to June 1997)
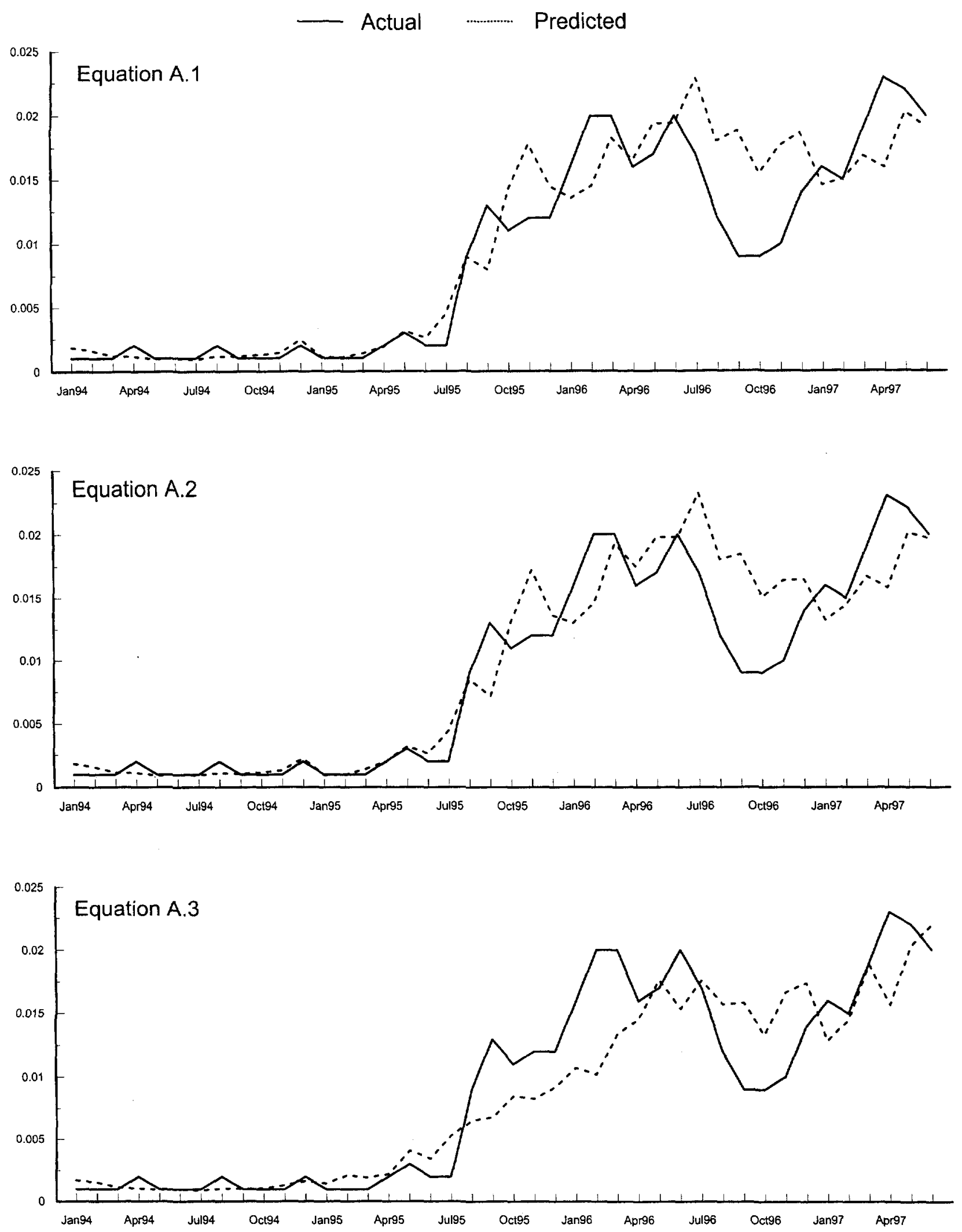
Figure 3

Actual and Predicted Values of Excess Liquid Assets over Deposits

(Dynamic simulation: July 1997 to October 1998)
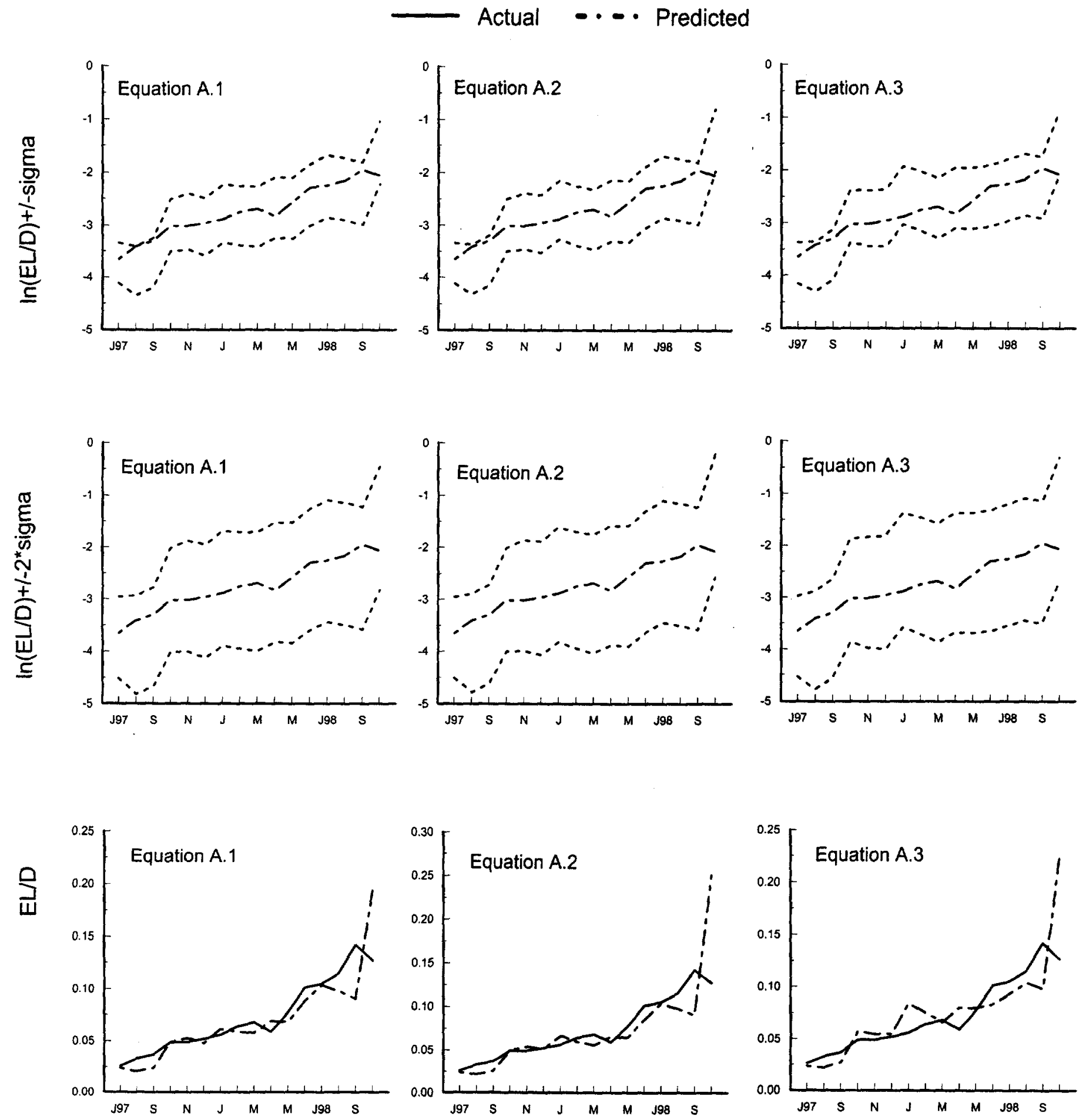
Table 1

Thailand: Determinants of Excess Liquid Assets (1992:01-1998:09)

\begin{tabular}{|c|c|c|c|c|c|c|}
\hline & \multicolumn{3}{|c|}{ A. Discount rate } & \multicolumn{3}{|c|}{ B. Money market rate } \\
\hline & (1) & (2) & (3) & (1) & (2) & (3) \\
\hline Constant & $\begin{array}{c}-21.42 \\
(10.51)\end{array}$ & $\begin{array}{r}-23.17 \\
(9.38)\end{array}$ & $\begin{array}{r}-23.94 \\
(6.82)\end{array}$ & $\begin{array}{l}-16.70 \\
(10.30)\end{array}$ & $\begin{array}{r}-18.84 \\
(9.40)\end{array}$ & $\begin{array}{r}-18.37 \\
(7.84)\end{array}$ \\
\hline $\ln (E L / D)[-0]$ & $\begin{array}{c}0.82 \\
(0.10)\end{array}$ & $\begin{array}{c}0.82 \\
(0.09)\end{array}$ & $\begin{array}{c}0.82 \\
(0.07)\end{array}$ & $\begin{array}{c}0.80 \\
(0.10)\end{array}$ & $\begin{array}{c}0.80 \\
(0.09)\end{array}$ & $\begin{array}{c}0.82 \\
(0.06)\end{array}$ \\
\hline $\ln (R R / D)$ & $\begin{array}{l}-7.73 \\
(3.84)\end{array}$ & $\begin{array}{c}-8.41 \\
(3.44)\end{array}$ & $\begin{array}{c}-8.66 \\
(2.56)\end{array}$ & $\begin{array}{l}-5.90 \\
(3.77)\end{array}$ & $\begin{array}{c}-6.66 \\
(3.47)\end{array}$ & $\begin{array}{l}-6.57 \\
(2.94)\end{array}$ \\
\hline $\mathrm{CV}(\mathrm{C} / \mathrm{D})$ & $\begin{array}{c}1.59 \\
(2.58)\end{array}$ & $\begin{array}{c}1.17 \\
(2.45)\end{array}$ & & $\begin{array}{c}0.77 \\
(2.56)\end{array}$ & $\begin{array}{c}0.15 \\
(2.39)\end{array}$ & \\
\hline $\mathrm{CV}_{Y N \mathrm{TT}}$ & $\begin{array}{c}-4.44 \\
(7.28)\end{array}$ & & & $\begin{array}{l}-4.50 \\
(7.03)\end{array}$ & & \\
\hline $\ln \left(Y / Y_{T}\right)$ & $\begin{array}{c}5.63 \\
(2.23)\end{array}$ & $\begin{array}{c}5.25 \\
(1.85)\end{array}$ & $\begin{array}{c}5.47 \\
(1.41)\end{array}$ & $\begin{array}{c}5.45 \\
(2.08)\end{array}$ & $\begin{array}{c}5.10 \\
(1.78)\end{array}$ & $\begin{array}{c}5.18 \\
(1.41)\end{array}$ \\
\hline Penalty rate & $\begin{array}{c}1.83 \\
(9.34)\end{array}$ & $\begin{array}{c}0.22 \\
(8.48)\end{array}$ & $\begin{array}{c}1.42 \\
(8.75)\end{array}$ & $\begin{array}{c}2.30 \\
(2.41)\end{array}$ & $\begin{array}{c}2.06 \\
(2.15)\end{array}$ & $\begin{array}{c}1.15 \\
(2.07)\end{array}$ \\
\hline $\begin{array}{l}\text { see } \\
-\end{array}$ & 0.391 & 0.379 & 0.397 & 0.376 & 0.367 & 0.379 \\
\hline $\mathrm{R}^{2}$ & 0.940 & 0.944 & 0.938 & 0.945 & 0.947 & 0.944 \\
\hline
\end{tabular}

Note: The dependent variable in the equations is the $(\log$ of $)$ the ratio of excess reserves to deposits, $\ln (\mathrm{EL} / \mathrm{D}))$. The regressors $\ln (\mathrm{EL} / \mathrm{D})[-0], \ln (\mathrm{RR} / \mathrm{D}), \mathrm{CV}(\mathrm{C} / \mathrm{D})$, $\mathrm{CV}_{\mathrm{Y} / \mathrm{T}}, \ln \left(\mathrm{Y} / \mathrm{Y}_{T}\right)$ and penalty rate denote respectively, the (logs of the excess reserves to deposits (minus the contemporaneous value) and of the rate of required reserves to deposits, the volatilities of the ratio of cash to deposits and of output to trend output, the (log of) the ratio of output to trend output, and the penalty rate proxied by the discount rate (panel A) and the money market rate (panel B). The estimates in the table correspond to the sum of the coefficients of the estimates of the lag polynomials, $a_{i}(L)$ for $p=3$ (see text for their precise definition), and their standard errors are shown in parenthesis. $\overrightarrow{\mathrm{R}}^{2}$ and see denote respectively the adjusted $\mathrm{R}$ squared and standard error of the regression. 



\section{Policy Research Working Paper Series}

Title

\begin{tabular}{|c|c|c|}
\hline WPS2468 & $\begin{array}{l}\text { Pricing, Subsidies, and the Poor: } \\
\text { Demand for Improved Water Services } \\
\text { in Central America }\end{array}$ & $\begin{array}{l}\text { Ian Walker } \\
\text { Fidel Ordoñez } \\
\text { Pedro Serrano } \\
\text { Jonathan Halpern }\end{array}$ \\
\hline WPS2469 & $\begin{array}{l}\text { Risk Shifting and Long-Term } \\
\text { Contracts: Evidence from the } \\
\text { Ras Gas Project }\end{array}$ & $\begin{array}{l}\text { Mansoor Dailami } \\
\text { Robert Hauswald }\end{array}$ \\
\hline WPS2470 & $\begin{array}{l}\text { Are Larger Countries Really More } \\
\text { Corrupt? }\end{array}$ & $\begin{array}{l}\text { Stephen Knack } \\
\text { Omar Azfar }\end{array}$ \\
\hline WPS2471 & $\begin{array}{l}\text { Validating Operational Food } \\
\text { Insecurity Indicators against a } \\
\text { Dynamic Benchmark: Evidence } \\
\text { from Mali }\end{array}$ & $\begin{array}{l}\text { Luc J. Christiaensen } \\
\text { Richard N. Boisvert } \\
\text { John Hoddinott }\end{array}$ \\
\hline WPS2472 & $\begin{array}{l}\text { Uzbekistan and Kazakkhstan: } \\
\text { A Tale of Two Transition Paths }\end{array}$ & $\begin{array}{l}\text { Asad Alam } \\
\text { Arup Banerji }\end{array}$ \\
\hline WPS2473 & $\begin{array}{l}\text { Banking Risks around the World: } \\
\text { The Implicit Safety Net Subsidy } \\
\text { Approach }\end{array}$ & Luc Laeven \\
\hline WPS2474 & Exports and Information Spillovers & $\begin{array}{l}\text { Alessandro Nicita } \\
\text { Marcelo Olarreaga }\end{array}$ \\
\hline WPS 2475 & $\begin{array}{l}\text { Industrial Growth and the Quality of } \\
\text { Institutions: What Do (Transition) } \\
\text { Economies Have to Gain from the } \\
\text { Rule of Law? }\end{array}$ & $\begin{array}{l}\text { David A. Grigorian } \\
\text { Albert Martinez }\end{array}$ \\
\hline WPS2476 & $\begin{array}{l}\text { Measuring Banking Efficiency in the } \\
\text { Pre- and Post-Liberalization } \\
\text { Environment: Evidence from the } \\
\text { Turkish Banking System }\end{array}$ & $\begin{array}{l}\text { Cevdet Denizer } \\
\text { Mustaía Dinç } \\
\text { Murat Tarimcilar }\end{array}$ \\
\hline WPS2477 & $\begin{array}{l}\text { Picking the Poor: Indicators for } \\
\text { Geographic Targeting in Peru }\end{array}$ & Norbert R. Schady \\
\hline WPS2478 & $\begin{array}{l}\text { Institutions, Politics, and Contracts: } \\
\text { The Attempt to Privatize the Water } \\
\text { and Sanitation Utility of Lima, Peru }\end{array}$ & $\begin{array}{l}\text { Lorena Alcázar } \\
\text { Lixin Colin Xu } \\
\text { Ana Maria Zuluaga }\end{array}$ \\
\hline WPS2479 & $\begin{array}{l}\text { Estimating the Effects of Corruption: } \\
\text { Implications for Bangladesh }\end{array}$ & $\begin{array}{l}\text { Aminur Rahman } \\
\text { Gregory Kisunko } \\
\text { Kapil Kapoor }\end{array}$ \\
\hline
\end{tabular}

\section{Contact for paper}

November $2000 \quad$ W. Nedrow 31585

November 2000

November 2000

November 2000

L. Henson 84026

November 2000

R. Vo 33722

November 2000

L. Tabada 36896

November 2000

A. Nelson 37117

November $2000 \quad$ M. Dinç 36233

$\begin{array}{ll}\text { November 2000 } & \begin{array}{l}\text { T. Gomez } \\ 32127\end{array} \\ \text { November 2000 } & \begin{array}{l}\text { P. Sintim-Aboagye } \\ 37644\end{array} \\ & \\ \text { November 2000 } & \text { S. Powell } \\ & 33526\end{array}$




\section{Policy Research Working Paper Series}

Title

WPS2480 Productivity Growth and Resource Degradation in Pakistan's Punjab:

A Decomposition Analysis

WPS2481 Foreign Direct Investment in Africa: Policies Also Matter

WPS2482 Can Institutions Resolve Ethnic Conflict?
Author

Mubarik Ali

Derek Byerlee

Jacques Morisset

William Easterly
Date

November 2000

November 2000

November 2000
Contact for paper

D. Byerlee 87287

N. Busjeet 33997

K. Labrie 31001 